\title{
Pelatihan Perencanaan Diri Terhadap Orientasi Masa Depan Remaja di Lembaga Pembinaan Khusus Anak (LPKA)
}

\author{
Nur Oktavia Hidayati, Efri Widianti, Aat Sriati, Titin Sutini , Imas Rafiyah \\ Taty Hernawaty, Suryani \\ Fakultas Keperawatan Universitas Padjadjaran \\ Email: nuroktaviah@gmail.com
}

\begin{abstract}
Abstrak
Remaja adalah kelompok beresiko mengalami masalah kesehatan, sesuai tahap perkembangannya, remaja berada pada masa transisi, pencarian identitas diri, apalagi khusus untuk remaja yang ada di Lembaga Pembinaan Khusus Anak (LPKA), selain mereka terisolasi dari lingkungan luar, kurangnya dukungan keluarga menyebabkan berbagai masalah seperti perasaan tidak berharga, malu dan kurang percaya diri, putus asa dengan masa depannya sehingga sangat diperlukan perhatian dan dukungan dalam merencanakan diri untuk masa depan mereka. Tujuan dari pengabdian pada masyarakat ini adalah membantu anak didik lapas (andikpas) untuk meningkatkan kemampuan dalam merencanakan diri untuk masa depannya. Metode yang dipergunakan dalam kegiatan ini adalah pelatihan bagaimana menyusun perencanaan diri untuk masa depan mereka. Luaran yang dihasilkan dalam kegiatan pengabdian kepada masyarakat ini adalah meningkatnya pengetahuan dan kemampuan andikpas dalam menyusun perencanaan diri. Kegiatan ini dihadiri oleh 35 andikpas. Hasil kegiatan terjadi peningkatan pengetahuan tentang orientasi masa depan dan kemampuan andikpas dalam penyusunan perencanaan diri. Melalui program pelatihan orientasi masa depan ini ternyata dapat menjadi salah satu solusi bagi permasalahan bagi andikpas dalam merencanakan diri mereka dalam menghadapi masa depan dan memberikan gambaran dan acuan untuk andikpas dalam menghadapi masa depan mereka setelah keluar dari LPKA.
\end{abstract}

Kata kunci : Andikpas, LPKA, masa depan, perencanaan diri, remaja.

\begin{abstract}
Adolescents are a group at risk of experiencing health problems, according to their developmental stages, adolescents are in a transition period, seeking self-identity, especially for adolescents in the Special Guidance for Children (LPKA), apart from being isolated from the outside environment, lack of family support causes various problems such as feelings of worthlessness, shame and lack of confidence, despair with the future so much needed attention and support in planning themselves for their future. The purpose of community service is to help prison students (andikpas) to improve their ability to plan themselves for their future. The method used in this activity is training how to plan themselves for their future. The output generated in this community service activity is the increased knowledge and ability of Andikpas in preparing self-planning. This activity was attended by 35 andikpas. The results of the activity have increased knowledge about future orientation and andikpas ability in the preparation of self-planning. Through this future orientation training program, it turns out that it can be one of the solutions to problems for andikpas in planning themselves in the face of the future and providing an overview and reference for Andikpas in facing their future after leaving LPKA.
\end{abstract}

Keywords : Andikpas, adolescents, future, LPKA, self-planning. 
Nur Oktavia : Pelatihan Perencanaan Diri Terhadap Orientasi Masa Depan Remaja

\section{Pendahuluan}

Remaja merupakan elemen penting dalam masyarakat, karena remaja adalah calon orangorang dewasa yang kelak memegang peranan penting dalam membangun masyarakat. Dalam tahapan perkembangan psikososial yang yang dikemukan Erikson, dinyatakan bahwa tugas utama yang dihadapi remaja adalah membentuk identitas personal yang stabil, kesadaran yang meliputi perubahan dalam pengalaman dan peran yang mereka miliki, dan memungkinkan mereka untuk menjembatani masa kanak-kanak yang telah mereka lewati dan masa dewasa yang akan mereka masuki (Stevens-Long \& Cobb, 1983).

Hal di atas sangat terkait erat dengan orientasi masa depan remaja. Dan di antara orientasi masa depan yang mulai diperhatikan pada usia remaja lebih terfokuskan dalam bidang pendidikan. Hal ini dinyatakan oleh Eccles (dalam Santrock, 2004), dimana usia remaja merupakan usia kritis karena remaja mulai memikirkan tentang prestasi yang dihasilkannya, dan prestasi ini terkait dengan bidang akademis mereka. Suatu prestasi dalam bidang akademis menjadi hal yang serius untuk diperhatikan, bahkan mereka sudah mampu membuat perkiraan kesuksesan dan kegagalan mereka ketika mereka memasuki usia dewasa (Santrock, 2001).

Penelitian yang dilakukan Bandura (dalam Santrock, 2001) terkait dengan prestasi remaja, diketahui kalau prestasi seorang remaja akan meningkat bila mereka membuat suatu tujuan yang spesifik, baik tujuan jangka panjang maupun jangka pendek. Selain itu, remaja juga harus membuat perencanaan untuk mencapai tujuan yang telah dibuat. Dalam proses pencapaian tujuan, remaja juga harus memperhatikan kemajuan yang mereka capai, dimana remaja diharapkan melakukan evaluasi terhadap tujuan, rencana, serta kemajuan yang telah mereka capai (Santrock, 2001), sehingga dapat dikatakan kalau orientasi masa depan yang dimiliki remaja akan lebih terkait dengan bidang pendidikan.

Dalam menentukan orientasi masa depan, keluarga (orangtua) mempunyai peran yang sangat besar. Menurut Gerald (1983), keluarga menyediakan 3 fungsi dasar sebelum, selama dan setelah masa remaja. 3 fungsi ini tidak sepenuhnya dapat digantikan oleh peergroups / struktur sosial yang lain sepanjang hidup. 3 fungsi tersebut adalah:

1. Keluarga menyediakan 'sense of cohesion'

Kohesi ini atau ikatan emosi membuat kondisi untuk identifikasi dengan kelompok dasar yang utama dan meningkat secara emosional, intelektual dan kedekatan fisik

2. Keluarga menyediakan model kemampuan adaptasi. 
Nur Oktavia : Pelatihan Perencanaan Diri Terhadap Orientasi Masa Depan Remaja

Keluarga mengilustrasikan melalui fungsi dasar bagaimana sebuah struktur kekuatan dapat berubah, bgaimana peran hubungan dapat berkembang dan begaimana peraturan hubungan dapat terbentuk. Remaja yang memiliki pengalaman tipe keluarga yang rigid (rendah tingkat adaptasinya) cenderung terinternalisasi gaya interaksi yang rigid. Sebaliknya, terlalu banyak kemampuan adaptasi dapat membuat gaya \&lsquo;chaotic\&rsquo;. Keseimbangan penting untuk fungsi ini, hal yang sama juga dengan kohesi.

3. Keluarga menyediakan sebuah jaringan komunikasi

Melalui pengalaman dimana individu belajar seni dari pembicaraan, interaksi, mendengarkan dan negosiasi.

Berdasarkan hal-hal di atas, anak remaja yang ada di Lembaga Pembinaan Khusus Anak (LPKA) tidak merasakan ketiga fungsi keluarga di atas karena fungsi itu tidak sepenuhnya dapat digantikan oleh peergroup atau struktur social yang lain sepanjang kehidupannya.

Sistem yang ada di LPKA yang memang tertutup dari dunia luar asrama dianggap kurang sesuai untuk pertumbuhan/perkembangan anak-anak. Sehingga hal tersebut dapat menimbulkan rasa kurang percaya diri, malu, tidak berguna, hal ini dapat mempengaruhi kemampuan pemecahan masalah pada diri remaja dan kejelasan orientasi masa depan remaja.

Perencanaan diri terhadap masa depan merupakan salah satu kegiatan yang penting dilakukan khususnya untuk andikpas yang sebagian besar berada pada tahap perkembangan remaja, dimana harapan dan cita-cita sangat tinggi untuk dicapai. Keadaan mereka yang berada di lingkungan yang terisolasi membuat mereka mudah putus asa dan menyerah sehingga harapan akan masa depan juga terasa sangat berat untuk dicapai. Berdasarkan analisis masalah yang ada di Lembaga Pembinaan Khusus Anak, maka rumusan masalah dalam kegiatan ini adalah belum adanya pelatihan perencanaan diri terhadapa orientasi masa depan andikpas di LPKA Bandung.

\section{Metode}

Metode pelaksanaan yang dilakukan dalam penerapan PPM ini, yaitu dilakukan dengan cara pelatihan dan pendampingan pada andikpas melalui kegiatan:

1. Pelatihan dan pembinaan andikpas secara berkesinambungan tentang perencanaan diri terhadap orientasi masa depan oleh tim PKM Fakultas. 
Nur Oktavia : Pelatihan Perencanaan Diri Terhadap Orientasi Masa Depan Remaja

Metode Pelaksanaan :

Tim pelaksana mempersiapkan andikpas berkoordinasi dengan petugas LPKA melakukan pre test terhadap andikpas yang telah ditunjuk untuk mengetahui sejauh mana pengetahuan andikpas terkait dengan pe;atihan yang akanm diberikan. Setelah itu, dilakukan pelatihan perencanaan diri terhadap orientasi masa depan dengan metode ceramah dan dilakukan diskusi pada akhir topik yang telah disampaikan dan kemudian diberikan post test setelah rangkaian kegiatan pelatihan selesai dilaksanakan.

2. Meningkatkan kemampuan andikpas dalam melakukan perencanaan diri terhadap orientasi masa depan.

\section{Metode Pelaksanaan :}

Tim pelaksana bekerjasama dengan petugas dan mahasiswa melakukan pendampingan pada andikpas untuk mempraktekkan membuat langkah-langkah perencanaan diri.

\section{Hasil}

Kegiatan dilaksanakan di Lembaga Pembinaan Khusus Anak (LPKA) dan dibagi beberapa tahap :

Tahap pertama dilaksanakan pada tanggal 30 September 2016, kegiatan diawali dengan pre test tentang materi yang akan disampaikan. Pre test ini berupa pilihan tunggal dengan jumlah soal sebanyak 10, sehingga andikpas hanya memilih satu dari jawaban yang paling benar. Kegiatan ini dihadiri oleh 35 andikpas. dari semua andikpas yang dilibatkan semua hadir dan mengerjakan soal yang diberikan dengan baik dan pihak LPKA memfasilitasi kegiatan ini. Hasil nilai tertinggi adalah 7 dan nilai terendah adalah 4. Adapun faktor penghambat dari kegiatan ini adalah ada beberapa andikpas yang terlambat datang dikarenakan ada jam kunjungan keluarga sehingga sedikit mengganggu pelaksanaan kegiatan. Tahap kedua dilaksanakan pada tanggal 1 Oktober 2016 yaitu kegiatan pelatihan perencanaan diri terhadap orientasi masa depan (pendidikan dan pekerjaan). Kegiatan dihadiri oleh 35 andikpas, pemateri dilakukan oleh tim keperawatan jiwa UNPAD, materi yang disampaikan meliputi konsep dan tahapan dalam perencanaan diri terhadap orientasi masa depan dibidang pendidikan dan pekerjaan. Andikpas hadir semua dan terlibat dengan baik serta pihak LPKA sangat memfasilitasi kegiatan ini. Kegiatan selanjutnya dilaksanakan pada tanggal 3 Oktober 2016, yaitu kegiatan praktek penyusunan tahapan perencanaan diri terhadap orientasi masa depan., dengan hasil semua andikpas dapat menyusun perencanaan diri sesuai tahapan . Kegiatan ini dihadiri 35 andikpas, tim pelaksana bekerjasama dengan mahasiswa dan petugas LPKA melakukan pendampingan kepada andikpas untuk mempraktekkan penyusunan tahapan perencanaan diri masing-masing, hasil dari kegiatan ini andikpas dapat melakukan penyusunan 
Nur Oktavia : Pelatihan Perencanaan Diri Terhadap Orientasi Masa Depan Remaja

perencanaan diri dengan baik, pihak LPKA juga sangat memfasilitasi kegiatan ini. Kegiatan terakhir adalah post test, kegiatan ini dilaksanakan pada tanggal 4 Oktober 2016, setelah matei selesai disampaikan, dilakukan post untuk mengukur kemampuan andikpas dalam menyerap informasi yang diberikan. Dalam kegiatan ini andikpas hadir semua dalam mengerjakan post test dan mengerjakan semua soal yang diberikan dengan baik. Hasil post test didapatkan peningkatan pengetahuan, nilai tertinggi 9 dan nilai terendah 7.

\section{Pembahasan}

Evaluasi dilakukan dengan Tim pelaksana bekerjasama dengan mahasiswa dan petugas LPKA, melakukan evaluasi dan pendampingan kepada andikpas untuk melakukan dan mempraktekkan kemampuan mereka dalam melakukan menyusun perencanaan diri

Hasil kegiatan PPM secara garis besar mencakup beberapa komponen sebagai berikut :

1. Keberrhasilan target jumlah peserta pelatihan

2. Ketercapaian tujuan pelatihan

3. Ketercapaian target materi yang telah direncanakan

4. Kemampuan peserta dalam penguasaan materi

Target peserta pelatihan seperti direncanakan sebelumnya adalah 35 andikpas. Dalam pelaksanaannya, kegiatan ini diikuti oleh 35 andikpas yang sudah melalui seleksi dari pihak LPKA. Dengan demikian dapat dikatakan bahwa target peserta tercapai $100 \%$. Angka tersebut menunjukkan bahwa kegiatan PPM dilihat dari jumlah peserta yang mengikuti dapat dikatakan berhasil. Ketercapaian tujuan pendampingan secara umum sudah baik dapat dilihat dari aktivitas peserta yang antusias mendengarkan dan mempraktekkan pemyususan perencanaan diri mereka. Ketercapain target materi pada kegiatan PPM ini cukup baik, karena materi telah disampaikan secara menyeluruh. Kemampuan peserta dilihat dari penguasaan materi, nilain pre dan post test sudah cukup baik yang terbukti adanya peningkatan nilai post test. Secara keseluruhan kegiatan pelatihan dapat dikatakan berhasil. Keberhasilan ini selain dilihat dari unsur-unsur diatas, dapat juga dilihat dari antusiame andikpas dan pihak LPKA yang mendukung kegiatan ini. 
Nur Oktavia : Pelatihan Perencanaan Diri Terhadap Orientasi Masa Depan Remaja

\section{Simpulan}

Pelatihan tentang perencanaan diri terhadap orientasi masa depan memang bermanfaat untuk meningkatakan pengetahuan andikpas LPKA Bandung. Peran serta andikpas dalam pelatihan menunjukkan antusiame mereka dalam meningkatkan kesejahteraan dan masa depan mereka kelak setelah keluar dari LPKA. Peran serta andikpas yang didukung oleh pihak LPKA sendiri menjadi nilai positif dalam meningkatkan orientasi masa depan andikpas di LPKA Bandung.

\section{Ucapan Terimakasih}

Kami mengucapkan banyak terima kasih kepada pihak-pihak yang sudah membantu atas terselenggaranya PPM ini, Universitas Padjadjaran yang telah memberikan kepercayaan kepada kami untuk melakukan kegiatan ini, pihak Fakultas Keperawatan yang telah memfasilitasi kami sehingga PPM ini berjalan dengan lancar. Petugas dan pihak LPKA atas kerja sama dan ijinnya sehingga kami dapat melakukan PPM ini. Andikpas yang terlibat yang telah bersedia berperan serta dan berkontribusi dalam PPM ini. Pihak-pihak terkait yang telah memberikan ijin bagi kami dalam melaksanakan kegiatan PPM ini, serta kontribusinya dan masukannya sehingga kegiatan PPM ini terselenggara dengan baik. Semoga kegiatan ini dapat dilaksanakan secara berkesinambungan dan bermanfaat untuk kita semua.

\section{Daftar Pustaka}

Arikunto, S (2002). Prosedur Penelitian : Suatu Pendekatan Praktek. Edisi Revisi V. Jakarta: PT Rineka Cipta.

Atkinson (1999). Pengantar Psikologi. Jakarta: Penerbit Erlangga.

Covey, Stephen R. 1994. "Tujuh Kebiasaan Manusia Yang Sangat Efektif”. Alih Bahasa Budijanto. "The Seven Habits of Highly Effective People". Jakarta: Binarupa Aksara

Hurlock, E.B (1998). Perkembangan Anak. Alih bahasa oleh Soedjarmo \& Istiwidayanti. Jakarta: Erlangga.

Lubis, Satria Hadi (2002). Breaking The Time. Jakarta. Kreasi Cerdas Utama

Mappiare, A. (1992). Psikologi Remaja. Surabaya: Usaha Nasional. 
Nur Oktavia : Pelatihan Perencanaan Diri Terhadap Orientasi Masa Depan Remaja

Notoatmojo, S (2002). Metodologi Penelitian Kesehatan. Edisi Revisi. Jakarta : PT Rineka Cipta.

Sugiyono (2001). Metode Penelitian Administrasi. Bandung. Alfabeta.

Wibowo, BS. etal, SHOOT, Sharpening Ourt Tools and Concept. TRUSTCO, Syamil, Bandung, 2002 